\title{
Pavement Planning on Jalan Pendidikan in Palembang City
}

\author{
Noor Sulistiyono ${ }^{1}$, Febriansyah ${ }^{2}$, Sri Kelana ${ }^{3}$, Muhammad Ilham Ghifari ${ }^{4}$ \\ Inland Water and Ferries Transport Polytechnic of Palembang, Palembang City, Indonesia
}

\begin{abstract}
Pavement as a pedestrian network is also an important element in the image of the city, along the road in the urban area all elements and attributes of the city are arranged, arranged and interconnected. People will observe and shape the imagination of the city area by moving through the streets (Kevin Lynch; 1962. Jalan Pendidikan is one of the roads in the Jakabaring District of Palembang City. This road is one of the areas in Palembang which is the center of education in Palembang. The length of this road is $\pm 1 \mathrm{~km}$ where there are many good schools ranging from kindergarten, elementary school, junior high school / MAN on this road section, including MAN 1 Palembang City, Palembang 19 Public High School, Palembang Junior High School and Sports High School, and 81 City Primary School Palembang. As long as this road has no pedestrian facilities, at the time of going and going to school this road is always crowded with pedestrians who want to go to school but still mixed with private vehicles so that it can cause congestion and conditions that are dangerous for pedestrians. From the results of the analysis obtained the highest volume of pedestrians that occurs on Monday at 06:00 WIB to 07.00 WIB with a number of 484 people. The highest pedestrians are from school children who go to school on foot.The width of the pavement plan is $\mathbf{2 . 4 2}$ meters, for safety the sidewalk must have a height higher than the road. For the type of sidewalk that is suitable that is the sidewalk on Rumija which is quite wide by adding a type of sidewalk that has a public transport stop.
\end{abstract}

Keywords:- (planning; pavement;safety;)

\section{INTRODUCTION}

The pavement also functions as a container or space for pedestrian activities in activities and as a form of service to pedestrians so that it can improve the smoothness, safety, comfort for pedestrians. Besides pedestrian lanes are public spaces where social interaction occurs between communities, in the urban context pedestrian lanes are special spaces for pedestrians that serve as a means of achievement that can protect pedestrians from conflicts with motorized vehicles.
Under Minister of Public Works regulation No. 06 / PRT / M / 2007 concerning the General Guidelines for Building and Environmental Management Plans, it has been stated that one of the structuring principles is to create a scale that is humane and pedestrian oriented. In an effort to create a pedestrian-oriented space, various guidelines, standards and rules that have been applied in Indonesia regarding the planning, provision and utilization of pedestrian networks in the provision of facilities and infrastructure, but besides that pedestrian paths are often only provided in moderation to meet the completeness of the road. Jalan Pendidikan is one of the roads in the Jakabaring District of Palembang City. This road is one of the areas in Palembang which is the center of education in Palembang. he role of government in relation to providing access and facilities for pedestrians is seen to be lacking. Safe, comfortable and humane pedestrian networks are important components that must be provided to increase the effectiveness of community mobility in creativity. In addition, integration of pedestrian paths with building layout, inter-environment accessibility and transportation systems has yet to be realized. These things certainly need to be handled by the Palembang City Government so that the potential problems created can be immediately overcome and pedestrian rights regained again.

\section{CASE PERSENTATION}

Jalan Pendidikan is one of the roads in the Jakabaring District of Palembang City. This road is one of the areas in Palembang which is the center of education in Palembang. The length of this road is $\pm 1 \mathrm{~km}$ where there are many good schools ranging from kindergarten, elementary school, junior high school / MAN on this road section, including MAN 1 Palembang City, Palembang 19 Public High School, Palembang Junior High School and Sports High School, and 81 City Primary School Palembang. As long as this road has no pedestrian facilities, at the time of going and going to school this road is always crowded with pedestrians who want to go to school but still mixed with private vehicles so that it can cause congestion and conditions that are dangerous for pedestrians. It is hoped that this research can be useful for planning sidewalks in the future. The analysis is carried out by counting the number of pedestrians using the side of the road so that it causes congestion on the education road, determining the width of the sidewalk that is suitable for pedestrians who cross and determining the type of sidewalk that is suitable on the road 


\section{LITERATUR REVIEW}

Pedestrians are everyone who walks Based on the 2014 Minister of Public Works Regulation. Pedestrians themselves are anyone who walks in the road traffic space, access for pedestrians is an important aspect of road traffic, facilities for pedestrians are the main conditions for running - Segments for pedestrians must be provided for all pedestrian activities. In the context of this study, pedestrians that will be discussed are pedestrians who use the road section of pedestrian traffic as access to carry out their activities. Pedestrians are people who do walking activities and are one of the elements of road users. (Decree of the Director General of Land Transportation: SK.43 / AJ 007 / DRJD / 97). Pedestrians must walk on the part of the road intended for pedestrians, or on the pedestrian section, or on the leftmost part of the road if there is no section of road that is intended for pedestrians (PP No. 43, 1993. Gunawan Wibowo (1998), In developing sidewalk suggestions it takes several criteria for the achievement of comfortable walking tips. Some rules in the placement of sidewalks and other supporting facilities:

A road section is deemed necessary to be equipped with a sidewalk if along the road there are land uses that have the potential to cause pedestrians. The land uses include housing, schools, shopping centers, trade centers, office centers, entertainment centers, social activity centers, industrial areas, bus terminals and others.

$>$ Placement of the sidewalk has been determined as placed on the left side of the shoulder of the road or the right side of the traffic lane (if parking lanes are available). However, if a plant path is available and is located on the left shoulder of the road or parking lot, the sidewalk must be made next to the path.

$>$ Placement of road equipment should in principle be placed on the inside or sides of the sidewalk.

$>$ If the sidewalk is directly adjacent to the land owned by an individual, the city greening facilities (trees, pots) should be planted on the inside of the sidewalk, but if there is sufficient space between the sidewalk and the land owned by the individual, then the city greening suggestion can be planted on the outside side of the sidewalk.

$>$ Open a ditch for drinases, the road must be located on the outside of the sidewalk. Closed sewers can be considered part of the sidewalk when covered with concrete slabs.

The sidewalks must be elevated.

In the Technical Guidelines for Planning Pavement Specifications (1990), in pavement planning that needs to be considered is the freedom of walking speed to precede other pedestrians and also the freedom of time to pass with other pedestrians without touching.

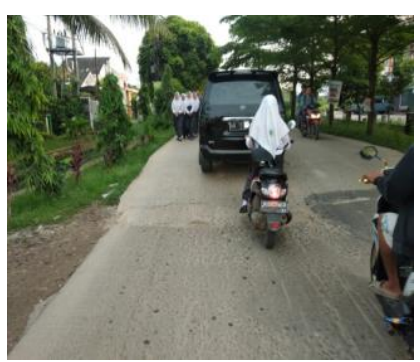

ISSN No:-2456-2165

Fig 1:- Pedestrian at the study site

\begin{tabular}{|c|c|}
\hline Use of Surrounding land & Minimum Width (m) \\
\hline Housing & 1.50 \\
\hline Office space & 2.00 \\
\hline Industry & 2.90 \\
\hline School & 2.00 \\
\hline Bus terminals / stops & 2.00 \\
\hline Shopping / shopping & 2.00 \\
\hline bridge & 1.00 \\
\hline
\end{tabular}

Table 1:- Width of sidewalk required according to surrounding land use

Source : Pedoman Teknis Perecanaan Spesifikasi Trotoar, 1991

\section{ANALYSIS}

Jalan Pendidikan is an education area and residential area. As for education that is in the way of Education that is starting from the 81th Elementary School of Palembang City, Palembang City Middle School and High School of Sports, MAN 1 Palembang City, and 19 Palembang High School. Pedestrians who pass this road are forced to use highway facilities because pedestrian facilities (sidewalks) are not yet available. Traffic jams often occur especially during hours of going and going to school.

Traffic jams often occur because of the large number of students who use road facilities so that vehicles and pedestrians are in 1 (one) road section and are also dangerous for pedestrians, public transportation and shuttle students. This research was conducted at the observation point near MAN 1 Palembang City.

\section{$>$ Pedestrian Volume}

Observation of the volume of pedestrians is the observation of the number of pedestrians entering the observed location. Observation of the number of pedestrians is carried out by counting the number of pedestrians entering the location of observations made in intervals of 15 minutes. After observation per point with time intervals per 15 minutes, we will get a recapitulation of the volume of pedestrians that have been carried out for 11 hours from 06:00 to 17:00. Recapitulation of pedestrian volumes at the observation point on Jalan Pendidikan 
ISSN No:-2456-2165

\begin{tabular}{|c|c|c|c|c|}
\hline \multirow{2}{*}{ Time } & \multicolumn{3}{|c|}{ Pedestrians Volumes (people) } \\
\cline { 2 - 5 } & Monday & Tuesday & Saturday & Monday \\
\hline $\begin{array}{c}06.00- \\
07.00\end{array}$ & 484 & 302 & 215 & 67 \\
\hline $07.00-08.00$ & 122 & 212 & 112 & 32 \\
\hline $08.00-09.00$ & 54 & 67 & 78 & 23 \\
\hline $09.00-10.00$ & 32 & 44 & 31 & 12 \\
\hline $10.00-11.00$ & 22 & 23 & 21 & 8 \\
\hline $11.00-12.00$ & 23 & 14 & 14 & 5 \\
\hline $12.00-13.00$ & 228 & 312 & 129 & 17 \\
\hline $13.00-14.00$ & 263 & 216 & 201 & 4 \\
\hline $14.00-15.00$ & 121 & 144 & 22 & 13 \\
\hline $15.00-16.00$ & 86 & 76 & 31 & 37 \\
\hline $16.00-17.00$ & 65 & 32 & 19 & 44 \\
\hline
\end{tabular}

Table 2:- Number of Pedestrian Volumes

From the table above, it is found that the highest foot length is in the workday because most pedestrians are from school students and then depicted in a graph.

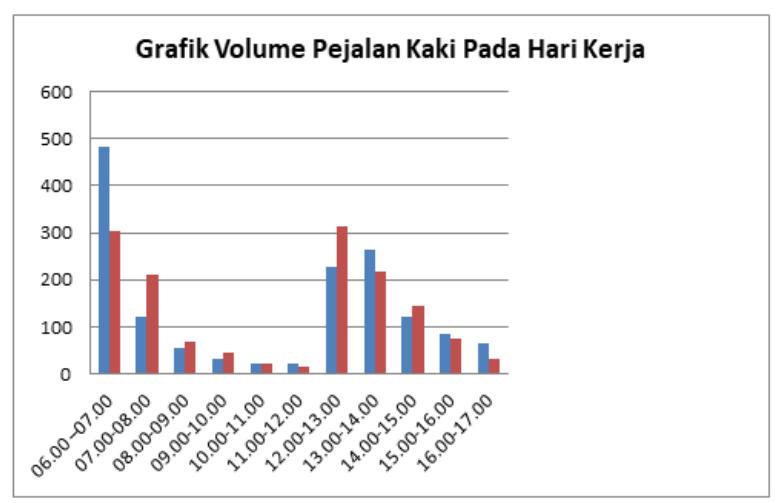

Fig 2:- Graph of Pedestrian Volumes in Working Days

From the picture above, the highest volume of pedestrians is obtained, which occurs on Monday at 06:00 WIB to 07.00 WIB with a total of 484 people. The highest pedestrians are from school children who go to school on foot.

\section{Volume Vehicle}

Vehicle volume observations are observations of the number of vehicles passing at the observed location, observations of the number of vehicles carried out by counting the number of vehicles passing at intervals per hour that have been carried out for 11 hours from 06.0017.00. Vehicle volume recapitulation at the observation point on Education Street. i.e. light vehicles (LV), heavy vehicles (heavy vehicles / HV), motorbikes (motor vehicles / MV) and non-motorized vehicles (un UMautirized / UM)

\begin{tabular}{|c|c|c|c|c|}
\hline \multirow{2}{*}{ Time } & \multicolumn{4}{|c|}{ Vehicle Volumes } \\
\cline { 2 - 5 } & \multicolumn{4}{|c|}{ Working Day (Monday) } \\
\cline { 2 - 5 } & LV & HV & MV & UM \\
\hline $06.00-07.00$ & 546 & 12 & 453 & 6 \\
\hline $07.00-08.00$ & 789 & 23 & 893 & 8 \\
\hline $08.00-09.00$ & 265 & 22 & 547 & 3 \\
\hline $09.00-10.00$ & 354 & 43 & 245 & 3 \\
\hline $10.00-11.00$ & 356 & 32 & 327 & 0 \\
\hline $11.00-12.00$ & 276 & 11 & 343 & 0 \\
\hline $12.00-13.00$ & 459 & 8 & 332 & 0 \\
\hline $13.00-14.00$ & 532 & 12 & 465 & 0 \\
\hline $14.00-15.00$ & 132 & 28 & 167 & 0 \\
\hline $15.00-16.00$ & 145 & 21 & 278 & 13 \\
\hline $16.00-17.00$ & 159 & 5 & 241 & 17 \\
\hline
\end{tabular}

Table 3

\section{Pavement Width Planning}

Sidewalks are needed in providing services both in terms of pedestrian comfort and safety. On Jalan Pendidikan is a school area and pedestrian facilities such as sidewalks are needed. To determine the effective width of the sidewalk, it is known that the highest pedestrian volume occurs at 06.00 WIB to 07.00 WIB because it is the time of entry for school students. From the observations it was found that the volume of pedestrians (v) for 15 minutes is 15 people / meter / minute and the education road is a school area, it is known that $\mathrm{N}=2.00 \mathrm{~m}$.

Then the width of the sidewalk plan :

$\mathrm{W}=\frac{V}{35}+N$

$\mathrm{W}=\frac{15}{35}+2$ meter

$\mathrm{W}=2,42$ meter.

The width of the planned sidewalk is 2.42 meters

\section{Equipment pavement}

The sidewalk should be equipped with several things:

- The facility path is the path between the sidewalk and the shoulder. This pathway is prepared for:

$\checkmark$ Placement of road equipment such as traffic signs, street lighting poles, etc.

$\checkmark$ Separating the movement of traffic flow of vehicles with pedestrian flows;

$\checkmark$ Provide free space for parking vehicles to open their doors.

\section{- Free space}

Free space that needs to be provided on the sidewalk is as follows:

$\checkmark$ vertical freedom of at least $2.5 \mathrm{~m}$ from the sidewalk surface

$\checkmark$ minimum depth of $1.00 \mathrm{~m}$ from the sidewalk surface

$\checkmark$ minimum side freedom (e) $0.30 \mathrm{~m}$ 


\section{Type of Pavement}

- The sidewalks on Rumija are quite wide

The Education Road has a road width of 7 meters and beside the left and right is a residential area that is still possible to build sidewalks with wide rumija that is complete with all the sidewalk elements. According to the Directorate General of Highways in the Pavement Planning Directive No. 007 / T / BNKT / 1990 general description of rumijja sidewalks which is quite wide as follows

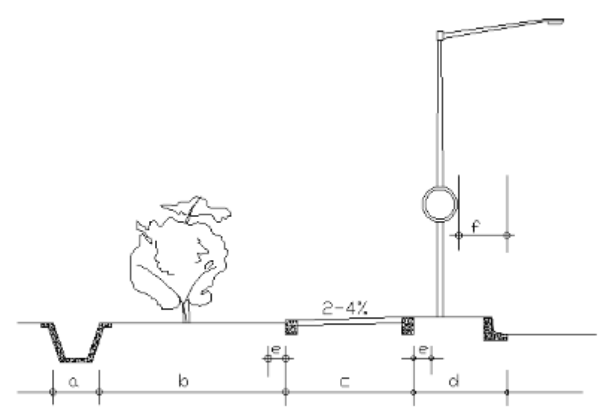

Fig 3:- Figure of sidewalk planning on Education Street

Caption:

$\checkmark$ Side channel (a), the amount will be carried out in further research

$\checkmark$ Parts of Rumija (b), whose width varies, can be used as: green lane, reserve land for widening the road, or other purposes planned at 1 meter

$\checkmark$ Sidewalks (c), the width is based on the calculation result which is $2.48 \mathrm{~m}$. The surface is tilted $2-4 \%$ to channel water from the Pavement pavement surface.

$\checkmark$ Facility lanes (d) can also be used as green lanes and lanes that separate traffic flows and pedestrian flows

$\checkmark$ Side freedoms for pedestrian paths (e), $0.30 \mathrm{~m}$

$\checkmark$ Freedom of traffic and can be used in the construction of public transport stop facilities (f), $0.60 \mathrm{~m}$

\section{- Sidewalks at Public Transport Stops}

Along the Education Road there are schools ranging from elementary to high school and on that road passed by public transport on the Ampera - OPI route so in front of the school can be carried out planning on the sidewalk at public transportation stops. The suitable type of sidewalk planned in front of the school is the sidewalk behind public transportation stops. According to the Directorate General of Highways in the Pavement Planning Directive No. $007 /$ T / BNKT / 1990 general description of sidewalks at public transportation stops as follows:

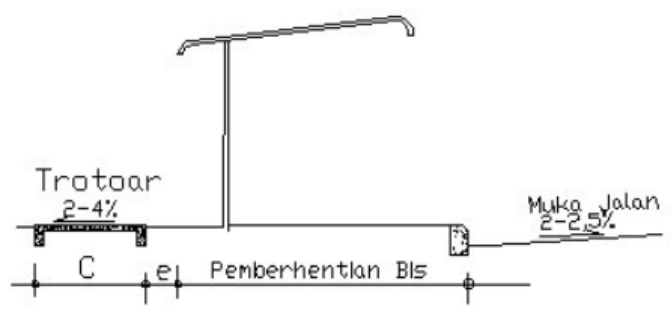

Fig 4:- Figure of Sidewalk Planning in Front of the School on Education Road
Information :

$\checkmark$ The sidewalk width (C) based on the calculation results is 2.42 meters with a slope of $2-4 \%$

$\checkmark$ Side freedom for the minimum pedestrian path (e), $0.30 \mathrm{~m}$

\section{CONCULSION}

Jalan Pendidikan is an education area and residential area. As for education that is in the way of Education that is starting from the 81th Elementary School of Palembang City, Palembang City Middle School and High School of Sports, MAN 1 Palembang City, and 19 Palembang High School. Pedestrians who pass this road are forced to use highway facilities because pedestrian facilities (sidewalks) are not yet available. Traffic jams often occur especially during hours of going and going to school.

As long as this road has no pedestrian facilities, at the time of going and going to school this road is always crowded with pedestrians who want to go to school but still mixed with private vehicles so that it can cause congestion and conditions that are dangerous for pedestrians. From the results of the analysis obtained the highest volume of pedestrians that occurs on Monday at 06:00 WIB to 07.00 WIB with a number of 484 people. The highest pedestrians are from school children who go to school on foot.The width of the pavement plan is 2.42 meters, for safety the sidewalk must have a height higher than the road. For the type of sidewalk that is suitable that is the sidewalk on Rumija which is quite wide by adding a type of sidewalk that has a public transport stop.

\section{REFERENCES}

[1]. Firdaus, Ormuz .(2013) 'Analisis Tingkat Pelayanan Jalan Pada Ruas Utama Kota Pangkal Pinang' Jurnal Forum Profesional Teknik Sipil Volume 1 No 1

[2]. Kusumo, Hanafi Suryo (2010) 'Analisis Perhitungan Tingkat Pelayanan (Level of Services) Pejalan Kaki pada Ruas Jalan Margonda (Ruas Jalan Antara Arif Rahman Hakim-Siliwangi Depok)' Universitas Indonesia

[3]. Pramona, Yulez dkk (2017) Analisa tingkat pelayanan dan kebutuhan infrastruktur pedestrian yang melintasi jalan TP. rustam Effendi, Jurnal Teknik Sipil Universitas Palembang Volume 7 No 13

[4]. Departemen Pekerjaan Umum. 1999. Direktorat Jendral Bina Marga, Pedoman Perencanaan Jalur Pejalan Kaki pada Jalan Umum.

[5]. Departemen Pekerjaan Umum. 1990. Direktorat Jenderal Bina Marga, Petunjuk Perencanaan Trotoar No. 007/T/BNKT/1990.

[6]. Departemen Pekerjaan Umum. 1995. Direktorat Jenderal Bina Marga, Tata Cara Perencanaan fasilitas Pejalan Kaki.

[7]. Departemen Pekerjaan Umum. 1995. Direktorat Jenderal Bina Marga, Tata Cara Perencanaan Fasilitas Pejalan Kaki di Kawasan Perkotaan No. 011/T/Bt/1995 